\title{
Status and Prospects of Energy Cooperation Between Ukraine and Turkey
}

\author{
Zaporozhchenko Anzhelika Serhiivna ${ }^{1,2, *}$
}

\author{
${ }^{1}$ Postgraduate Student of the Department of International Relations and Foreign Policy, Petro Mohyla Black Sea \\ National University (Ukraine, Mykolaiv), Ukraine \\ 2 Policy, Petro Mohyla Black Sea National University, Mykolaiv, Mykolaiv Region, 54003, Ukraine \\ *Corresponding author. Email: anzhelikaz1993@gmail.com
}

\begin{abstract}
Cooperation in the energy sector is one of the areas for strategic cooperation between Ukraine and Turkey. The interests of both countries in the field of energy are similar: the need to diversify energy sources, ensure security of energy supply, active use of own transit potential, exploration and production of its own energy resources. Relations in this direction include the following areas: production and distribution of crude oil, natural gas, coal and metal ores, exchange of technologies, construction of pipelines and oil terminals, cooperation in the development of alternative energy sources and atoms for peace. The cooperation was established in 1986, when the Agreement was concluded between the Government of the Union of Soviet Socialist Republics and the Government of the Socialist Republic of Romania on the transit of Soviet natural gas through the territory of the Socialist Republic of Romania to Turkey, Greece and other countries. The year of 2020 became a landmark for Turkey, as the TurkStream gas pipeline (the first branch) to SouthEastern Europe was launched, and gas deposits were found in the Black Sea. As a result, Turkey ceased to be dependent on Ukrainian gas for gas transportation, and Ukraine's position in cooperation with Turkey became weaker. At present, cooperation between Ukraine and Turkey (on the part of energy) in the use of a peaceful atom, the development and use of alternative energy sources is promising, but the cooperation in the area of oil and gas transportation has turned out to be most failed for Ukraine that demonstrates Turkey's dominant position concerning Ukraine in the field of gas transportation in the Black Sea region.
\end{abstract}

Keywords: Ukraine, Turkey, transportation of gas, coal, alternative energy sources, peaceful atom

\section{INTRODUCTION}

Almost all countries with access to the Black Sea are energy dependent to varying degrees, but the exception is the Russian Federation, which is a supplier of oil and gas. The following data for 1990-2019 illustrate the extent to which Ukraine and Turkey are dependent on energy imports, in particular, the table presents the almost complete lack of energy reserves of Turkey and the partial dependence of Ukraine. At the same time, it is necessary to make allowances for the fact that in the summer of 2020, Turkey discovered gas deposits in the Black Sea shelf near the Turkish coast [1].

Table 1 Energy performance of Ukraine and Turkey in comparison [2].

\begin{tabular}{|c|c|c|c|c|}
\hline $\begin{array}{l}\text { Country/ } \\
\text { Indicator }\end{array}$ & $\begin{array}{c}\text { Energy } \\
\text { production, } \\
\mathbf{2 0 1 9}\end{array}$ & $\begin{array}{c}\text { Energy } \\
\text { consumption (total } \\
\text { and by categories), } \\
2019\end{array}$ & Energy reserves [3] & $\begin{array}{c}\text { Evolution of } \\
\text { consumption: } 1990 \\
\text { and } 2019\end{array}$ \\
\hline Ukraine & $\begin{array}{c}\text { 60 Mtoe } \\
\text { Electricity- } 37 \% \\
\text { Gas }-37 \% \\
\text { Coal }-23 \% \\
\text { Biomass }-7 \% \\
\text { Oil }-4 \% \\
\text { Thermal energy - } \\
1 \%\end{array}$ & $\begin{array}{c}\text { 89 Mtoe } \\
\text { Coal }-29 \% \\
\text { Gas }-26 \% \\
\text { Electricity }-25 \% \\
\text { Oil }-15 \% \\
\text { Biomass }-4 \% \\
\text { Thermal energy }-1 \%\end{array}$ & $\begin{array}{l}\text { Uranium (thousand tons of U): up to } 40 \text { USD } \\
\text { per kg of U - } 2.5 \text {; up to } 80 \text { USD per kg of U - } \\
38.7 \text {; up to } 130 \text { USD per kg of U - 76.0; up to } \\
260 \text { USD per kg of U }-142.4 \\
\text { Technical hydropower potential (million tef } 1 \text { / } \\
\text { year): }-2.706 \text {, level of use }-59.2 \% \text {. } \\
\text { Crude oil - } 0.084 \text { billion tef. } \\
\text { Natural gas }-1.470 \text { billion tef. } \\
\text { Coal - } 26.539 \text { billion tef }\end{array}$ & $\begin{array}{l}250 \text { Mtoe }-1990 \\
89 \text { Mtoe - } 2019 \\
\text { Waveform drop in } \\
\text { energy consumption }\end{array}$ \\
\hline
\end{tabular}

${ }^{1}$ Tons of equivalent fuel 


\begin{tabular}{|c|c|c|c|c|}
\hline Turkey & $\begin{array}{c}\mathbf{4 8} \text { Mtoe } \\
\text { Electricity }-39 \% \\
\text { Coal }-37 \% \\
\text { Biomass }-9 \% \\
\text { Oil }-8 \% \\
\text { Thermal energy - } \\
6 \% \\
\text { Gas }-1 \%\end{array}$ & $\begin{array}{c}\text { 147 Mtoe } \\
\text { Oil }-29 \% \\
\text { Coal }-28 \% \\
\text { Gas }-25 \% \\
\text { Electricity }-13 \% \\
\text { Biomass }-3 \% \\
\text { Thermal energy }-2 \%\end{array}$ & $\begin{array}{c}\text { Uranium (thousand tons of U): } \\
\text { Up to } 130 \text { USD per kg of U }-7.3 \\
\text { Up to } 260 \text { USD per kg of U }-7.3 \\
\text { Technical hydropower potential (million } \\
\text { tef/year): } \\
-26.568 \text {. } \\
\text { Level of use }-23.7 \% \\
\text { Crude oil - } 0.058 \text { billion tef. } \\
\text { Natural gas }-0.008 \text { billion tef. } \\
\text { Coal - } 2.895 \text { billion tef }\end{array}$ & $\begin{array}{c}51 \text { Mtoe }-1990 \\
147 \text { Mtoe }-2019 \\
\text { Waveform rise in } \\
\text { energy consumption }\end{array}$ \\
\hline
\end{tabular}

Therefore, Ukraine and Turkey are energy dependent, while Turkey is dependent to greater extent. So, their cooperation in the energy sector is extremely important, as it provides energy security for both countries through diversification of energy supplies: strengthening positions in the transit of oil and gas, construction of terminals for the supply of liquefied gas, exploration for gas production on the Black Sea shelf. It should be noted that cooperation in this direction is extremely important for Ukraine, but rivalry in the transportation of energy resources to Europe may reduce the transit role of Ukraine and weaken its position in the international arena.

\section{PROBLEMS AND METHODOLOGY}

It will be recalled that according to the analytical report of the Centre for Global Studies "Trends of the security situation in the Black Sea region" (July 2020) the dependence of most countries in the Black Sea region on gas imports was over $80 \%$ in 2018 , except Ukraine and Romania, where dependence did not exceed $50 \%$. Most countries are heavily dependent on oil imports, and Ukraine and Turkey also import coal (as for Ukraine, this trend has become more relevant after 2014). Despite the fact that Ukraine stopped purchasing Russian natural gas in 2015, it continues to depend on Russian supplies of petroleum products, liquefied gas and coal. In 2015-2019, the share of imports of petroleum products from Russia ranged from $17 \%$ to $41.3 \%$. The total share of handling petroleum products from Russia and Belarus, which receives Russian oil on preferential terms, reaches $75 \%$ [4]. Turkey receives Russian gas through two branches: Blue Stream and the TurkStream branch launched in January 2020 (the first branch). It is also possible to add the construction Akkuyu NPP in Turkey by Russian companies, which is an important factor in TurkishRussian energy cooperation and reduces Ukraine's value as a partner for energy cooperation.

Therefore, the low availability of energy resources in both countries and dependence on Russian energy sources in both Ukraine and Turkey make their cooperation an urgent need to reduce such dependence by ensuring energy supplies from Central Asian countries.

However, their cooperation in this area is hardly considered by scientists. And the researches we have been able to have a look at indirectly consider the cooperation of countries among other areas only. Among Ukrainian researchers, the importance of cooperation in the field of energy in Ukraine and Turkey is pointed out by such
Ukrainian scientists as O. Mavrina [5], O. Koliada [6], R. Enverov [7], O. Vladymyr and L. Maliuta [8]. As for Turkish researchers, there are few of them and they have mostly drawn attention to the need for Turkish-Ukrainian cooperation in the energy sector, but pointed to political instability in Ukraine, which threatens gas supplies to Turkey. And the second aspect is that these relations are considered only through the prism of Turkish-Russian energy relations. In particular, among such scientists it is worth mentioning: C emal Kakişim [9], who writes about Ukraine's transit role and Russia's desire to reduce it, and adds that the construction of the TurkStream will serve to increase Turkey's confidence in gas transportation, which was impossible due to instability in Ukraine. Gareth $\mathrm{M}$. Winrow [10] notes that Ukraine is one of the countries that is both a transit country and a consumer of gas and that one of the reasons why Russia has decided to build a gas pipeline bypassing Ukraine is the latter's pricing policy for gas transportation. Professor İlyas Kemaloğlu notes that due to the fact that Ukraine has not achieved political stability, this fact has a negative impact on cooperation, and is a major obstacle to a true "strategic partnership". He adds that on the other hand, relations with Ukraine are overshadowed by Russian relations. Thus, due to tensions between Russia and Ukraine, Ankara's relations with Kyiv depend in part on the course of events along the Ankara-Moscow line. Emphasizing the Turkish-Ukrainian energy cooperation, he points out that in this area the countries are competitors [11].

Therefore, the situation and prospects of cooperation between Ukraine and Turkey in the energy sector is a scantily researched topic that demonstrates its topicality. The purpose of our research is to analyse the situation and peculiarities of cooperation between Ukraine and Turkey in the energy sector and to clarify the prospects for cooperation in this area. The tasks set out by us to unfold the topic are: analyse the degree of scientific development and the source base of the research; identify areas in the energy sector in which Ukraine and Turkey cooperate and analyse the depth of this cooperation; to offer prospects of Ukrainian-Turkish cooperation in the field of energy. In order to research the topic, the author used global websites with energy production and energy use statistics, documentary base (international agreements, minutes of meetings, legislation of Ukraine), websites of ministries and information from the media. 


\section{RESULTS AND DISCUSSION}

\subsection{Regulatory and legal of Ukrainian- Turkish relations in the field of energy}

Regulatory and legal relations are quite extensive, it covers all areas of cooperation and illustrates the evolution of the documentary base: from concluding memoranda, general agreements and treaties in all areas of energy cooperation to agreements on deepening cooperation in specific areas (nuclear energy, coal, etc.). It should be noted here that the strengthening of cooperation according to the analysis of the regulatory and legal framework was available in the field of carbohydrates and the use of the peaceful atom. The analysis of the documentary base also shows the suspension of activities in concluding agreements in the energy sector in 2011. To implement Ukrainian-Turkish relations in the economy, the Intergovernmental Ukrainian-Turkish Commission on Trade and Economic Cooperation was established, which included a working group on cooperation in the field of fuel and energy, and was more concerned with cooperation in the field of energy during the Commission meetings.

The Protocol on Cooperation between the Government of Ukraine and the Government of the Republic of Turkey of October 28, 1993, which entered into force immediately, became the general document initiating Ukrainian-Turkish cooperation in the field of energy [12]. It provided for opportunities for cooperation in the fields: production of oil, natural gas, coal and metal ores, technology exchange, construction of pipelines and oil terminals, intensification of contacts, and a joint working group was agreed to be established under it. Ukraine and Turkey, given the congestion traffic through the Bosporus and Dardanelles, decided to develop joint projects for the transit of oil and petroleum products for the needs of Ukraine through pipelines through the territory of Turkey, bypassing the Straits. Botaş Company was entrusted with the case on behalf of Turkey, and Ukrzarubezhnaftogazbud Company was from Ukraine. The countries agreed on joint financing of projects to be implemented in both countries, on joint work on their implementation and maintenance in good condition

On June 18, 1997, energy cooperation in the oil sector was deepened - the Agreement was signed between the Government of Ukraine and the Government of the Republic of Turkey on the Ceyhan-Samsun oil pipeline system [13], which was ratified on December 17, 1997. [14]. The reason for the signing was the congestion of the Bosporus and Dardanelles Straits, and the goal was to avoid pollution and to unload them. The agreement was Ukraine's desire to transport crude oil from a terminal planned to be built on Turkey's Mediterranean coast to Turkey's Black Sea coast. It was to be transported through the territory of Turkey, in particular, to meet Ukraine's needs in crude oil. The same companies became responsible: Botaş and Ukrzarubezhnaftogazbud. The
Turkish side guaranteed assistance and many privileges for Ukraine: acquisition and transfer of land for the pipeline system construction at prices corresponding to average market prices for similar land, exemption from all taxes, duties, fees and any other financial penalties on material and technical products, including machinery, equipment and other facilities that are temporarily transferred into Turkish territory for use in the construction of facilities provided by the Project. Ukrzakordonaftogazbud was granted permission to open offices in the Mediterranean and Black Sea terminals. The owner of the pipeline system was to be a UkrainianTurkish joint venture.

Such conditions were favorable for Ukraine, especially when in the ratification of the Agreement, paragraph 1 of Article 5 subparagraph 1.3 was excluded, which stated the obligations of Ukrzakordonaftogazbud to ensure the load of the pipeline system in the amount of not less than 25 million tons per year [14].

On June 7, 2005, the Memorandum of Understanding was signed between the State Nuclear Regulatory Committee of Ukraine and the State Atomic Energy Agency of the Republic of Turkey on technical cooperation and exchange of information in the field of nuclear regulation, which entered into force on September 8, 2005. [15]. The State Nuclear Regulatory Committee of Ukraine and the State Atomic Energy Agency of the Republic of Turkey, referring to the Agreement between the Cabinet of Ministers of Ukraine and the Government of the Republic of Turkey on Operational Notification of Nuclear Accidents and Exchange of Information on Nuclear Installations of 23 November 2000, agreed to cooperate in areas such as: regulatory control over the safe use of nuclear energy, emergency preparedness and crisis response, safety research on licensing and supervision of nuclear installations, safety and security of nuclear installations, safety and security of radioactive sources, organization and conduct of safety analyses in the transportation of nuclear materials, transportation safety of radioactive materials, safety of radioactive wastes, development, physical protection of nuclear materials and nuclear installations and prevention of illicit trafficking in nuclear and radioactive materials, accounting and control of nuclear materials, radiation protection, quality control of equipment affecting the safety of nuclear installations, establishment and development of institutions for scientific and technical support of nuclear and radiation safety regulatory authorities, training and retraining of specialists of regulatory, nuclear and radiation safety authorities, or in other fields determined by mutual consent of the countries [16].

On the same day, in addition to the Memorandum, the Agreement on Cooperation in the Energy Sector was signed, which entered into force in 2011. [17]. The Governments of Ukraine and Turkey agreed on mutually beneficial cooperation and recognized the Ministry of Fuel and Energy of Ukraine and the Ministry of Energy and Natural Resources of the Republic of Turkey as competent authorities in the implementation of the Agreement. Specific agreements concerned the production, 
transmission and distribution of electricity, the implementation of investment projects in both countries and third countries, operation, maintenance and reconstruction of power plants and networks, the sphere of research, design and construction in the field of energy, information exchange, including on the peaceful uses of nuclear energy, the use of transit pipelines and underground gas storage facilities.

On March 28, 2007, the Intergovernmental Commission on Trade and Economic Cooperation between Turkey and Ukraine approved the minutes of meeting, including cooperation in energy sector [18]. The factor of bringing the energy sector of cooperation to the highest level was especially important. The countries agreed to set up a joint venture on the basis of the Turkish Petroleum Corporation (TPAO) and the Ukrainian Naftogaz and Chornomornaftogaz companies as soon as possible, and to set up a joint working group to carry out joint exploration and production. They also agreed for further cooperation in the transportation of Russian gas. Ukraine offered to cooperate to ensure the participation of Ukrainian companies in the Nabucco project, and Turkey stated that Botaş Company (Boru Hatları ile Petrol Taş A.Ş.) would notify the company's partners of this request. There was an exchange of information, which was recorded in the minutes. Ukraine was provided with information on the implementation phase of the Samsun-Ceyhan oil pipeline project and Ukrnaftagaz National Joint Stock Company expressed a desire to participate in its implementation and preparation of commercial proposals. Turkey expressed interest in the project and development of the OdesaBrody oil pipeline to transport oil to Europe.

The next topic of the talks was the exchange of knowledge and experience on electricity generation, transmission, distribution and trade between the respective electricity companies of the two countries. Turkey was interested in the mining industry in Ukraine and agreed to intensify cooperation on security measures in the use of nuclear energy [18].

The Memorandum in the Coal Industry, signed on January 25,2011 , continued the improvement of the regulatory framework of Ukrainian-Turkish cooperation in all spheres of energy (it came into force for Ukraine immediately). According to it, the relevant Ministries of Energy of Ukraine and the Republic of Turkey were to create a basis for joint institutional cooperation and encourage bilateral cooperation in such areas: renewable power generation, trade and supply of electricity, mining, hydrocarbons, cooperation in the field of nuclear energy [19]. Regarding renewable energy, the parties agreed to identify and develop joint projects on the use of renewable energy sources, industrial cooperation and marketing, electricity generation systems in both countries, in the field of geothermal energy for the use, development and management of geothermal resources. They expressed their readiness to study opportunities in the implementation of joint projects for the modernization and construction of new hydropower plants, hydroelectric power plants, small hydropower plants, and electromechanical equipment for hydropower plants, turbine design, production of turbines and generators and transformer substations.

Cooperation in the field of electrical energy, trade and supply provided support for the third stage of the study under the Power Transmission Planning Project in the Black Sea Region for further opportunities for energy exchange and trade between the two countries. Cooperation in the field of mining involved consultations between public and private institutions on the development of deposits and marketing of mines and their derivatives in both countries, in particular: implementation of joint projects in the direction of research of coal deposits; technological improvement of coal mining and occupational safety and health; cooperation in the management of underground coal systems, coal purification technologies, coal gasification, coal processing (including enrichment), briquetting, technology of complex combined cycle gasification and advanced combustion technologies; use of coal and coal derivatives in agriculture, industry, etc. [19].

Cooperation in the field of hydrocarbons was aimed at elaborating general principles for the development of hydrocarbon resources; development of environmentally safe, socially and economically sound projects in the field of marine and land exploration, production and transportation of hydrocarbons in Ukraine, Turkey, the Black Sea and in third countries; 2D/3D seismic research in marine geology, geophysics, oceanography and hydrography; implementation of projects for exploration and technological development of gas hydrates; improving mechanisms for informing, reducing the impact and responding quickly to emergencies in order to prevent disruptions in the supply of natural gas to Turkey through Ukraine; trade in crude oil and petroleum products.

Cooperation in the field of nuclear energy provided for: improving nuclear and radiation safety, emergency response and physical protection; design, construction, operation and decommissioning of nuclear facilities; handling spent nuclear fuel and radioactive wastes; training of personnel for NPPs and their advanced training [20].

We summarize that, as noted at the beginning of the section, the regulatory and legal framework for energy cooperation between Ukraine and Turkey fixes the main directions: exploration, production and transportation of hydrocarbons, coal industry, renewable energy, use of the peaceful atom, and electrical energy. The main areas of cooperation were the creation of joint projects and ventures, exchange of information and knowledge. The most profound areas are cooperation in the hydrocarbon and nuclear industries. The development of new bilateral documents became less active after 2011, which is due to the low interest of the Ukrainian side and the events of 2014 (annexation of the Crimea and the beginning of hostilities in eastern Ukraine). 


\subsection{Transit and extraction of gas and oil}

As mentioned above, the transit of gas to Turkey through Ukrainian territory was ensured by the 1986 Agreement [21]. This Agreement is in force, but after the launch of TurkStream, Gazprom has significantly reduced gas supplies via the Trans-Balkan gas pipeline through Ukraine to Bulgaria, Turkey, Greece and Macedonia This route is currently used only for transportation of small volumes of gas for Romania, about 5 million cubic meters per day [22].

In general, cooperation between Ukraine and Turkey in this area held good promise. The Ministry of Economic Development and Trade of Ukraine characterized Ukrainian-Turkish cooperation in the field in the early 2000s as follows: "currently, this element of promising partnership is primarily characterized by unilateral actions of both countries aimed at ensuring energy security through the development or modernization of oil and gas transportation systems, diversification of sources and ways of energy supply, exploration or development of energy resources in their territories." [23]. Projects on implementation of energy programs for modernization of gas transmission system and other objects of energy infrastructure of Ukraine were forecasted as key practical interest for both countries. The priorities for Turkey are: creation of the nuclear energy sector, construction of hydroelectric power plants, gas and oil pipelines, initiation of joint activities in bilateral or multilateral format in the field of joint exploration and production of energy resources on the Black Sea shelf and in third countries. It was planned to use the Ukrainian experience and available capacity in the construction and operation of oil and gas pipelines, active participation in the construction and expansion of existing pipelines, in particular, in international projects for the construction of the Nabucco Gas Pipeline and the Samsun-Ceyhan Oil Pipeline. Therefore, the Ukrainian Sumy Machine-Building Research and Production Association named after M. V. Frunze, as well as the Ukrainian Metinvest Metallurgical Company began to work actively with Turkey.

During the meetings of 2015-2016, Ukraine and Turkey decided to continue cooperation in the field of construction of underground gas storage facilities, nuclear-power engineering, alternative energy sources, energy saving technologies, etc. As was evident from the regulatory and legal framework of cooperation, Ukraine expressed readiness to participate in projects for the construction of oil and gas pipelines in Turkey, as well as joint production of hydrocarbons on the Black Sea shelf: Nabucco, Samsun-Ceyhan projects, declared a desire to participate in the construction and operation of the TransAnatolian Pipeline (TANAP) (2012). However, Ukraine's potential participation is still not fully realized.

The report of the Cabinet of Ministers for 2015 allows drawing conclusions about the state of implementation of the main priorities of Ukraine in relation to Turkey. A key issue in the Energy Independence Program was the construction of an LNG terminal, and it was necessary to agree with the Turkish side to allow LNG tankers to pass through the Bosporus and Dardanelles Straits. Given that LNG in maritime law is characterized as dangerous cargo, it is necessary to obtain the consent of the Turkish side for the passage of LNG tankers, and it has never been given yet. Turkey's refusal is formally due to environmental and technical considerations. But the results of negotiations between Kyiv and Ankara on the passage of LNG tankers through the straits are not known to the general public [24].

In 2016, during the 10th meeting of the Ukrainian-Turkish intergovernmental commission on trade and economic cooperation, the possibility of Ukraine's accession to the Southern Gas Corridor project in case of proving economic feasibility and ensuring non-discriminatory access to the relevant facilities was discussed [25].

As a conclusion to this subparagraph, it should be noted that the stated goals of Ukraine and Turkey to cooperate in the framework of international projects for the construction of the Nabucco Gas Pipeline and the Samsun-Ceyhan Oil Pipeline remain mere projects and they have not been fully implemented by Ukraine. The permission for LNG tankers to pass through the Bosporus and Dardanelles Straits for the Ukrainian LNG terminal has not been obtained from Turkey yet. From there, Ukraine cannot coordinate its energy policy with Turkey, as the latter cares about its own interests in ensuring its own energy security and its possible transformation into a global energy hub, and Ukraine has failed to provide strong arguments to convince Turkey.

\subsection{Nuclear power}

In 2016, following the 10th meeting of the UkrainianTurkish intergovernmental commission on trade and economic cooperation, it was announced that Ukraine and Turkey agreed to cooperate in the field of nuclear energy, aircraft construction and development of transit corridors, joint construction projects, facilitating access for Ukrainian metallurgists into the Turkish market. Arguing for cooperation in nuclear energy, the head of the Ukrainian delegation said that the parties agreed to provide Ukraine with nuclear safety consulting services to Ukraine, training of all categories of NPP personnel, internships for Turkish students and graduate students in Ukraine. The next area of energy for discussion was energy efficiency. In particular, it was about designing new "green houses" [25].

On January 9, 2016, the Turkish media reported that after the Russian National University of Nuclear Research cancelled the agreement providing for the training of personnel for the nuclear power plant under construction in Mersin Akkuyu, the establishment of such cooperation with Ukraine was on the agenda as it had extensive experience in that field. To implement this idea, the Embassy of Ukraine in Ankara sent a letter to Ukrainian universities to share their nuclear experience with the University of Ankara [26].

On December 5, 2019, the State Enterprise "State Scientific and Technical Centre for Nuclear and Radiation 
Safety" and the Institute of Nuclear Research of Ankara University signed an agreement on cooperation in the field of training specialists in the field of nuclear energy. At the beginning of October this year, a protocol has been signed, according to which a group of students from Ankara University began studying at the National Technical University of Ukraine "Kyiv Polytechnic Institute named after Ihor Sikorskyi" in February 2020 [27].

Thus, despite all the projects and envisaged areas of cooperation in the nuclear field, the importance for Ukraine to cooperate with Turkey in the field of development and use of the peaceful atom, Ukraine participates only in the training of Turkish specialists. In this area, as well as in hydrocarbons, Ukraine has not used its potential, even given the large reserves of uranium and the operational practice of nuclear power plants.

\subsection{Coal energy}

On February 15, 2012, after the meeting of parliamentary delegations of Ukraine and Turkey, the Minister of Energy and Natural Resources of Turkey Taner Yildiz stated that the parties agreed to resolve problems related to adverse weather conditions, and thanked Ukraine for agreeing to provide gas from its own warehouses in winter. The Minister added that the possibilities of developing coal deposits and renewable energy sources together with Ukraine were discussed, especially in winter, when the use of natural gas increased way more. He noted that Ukraine is the richest country in the region in terms of gas deposits. He called Ukraine's experience in operations related to the operation of nuclear power plants together with a joint nuclear power plant to be useful for Turkey [28].

Given the data in Table 1 in the introduction and the fact that most of the energy reserves of Turkey are coal, the Minister's proposal to share experience in the use of coal technology is logical.

Despite a significant drop in coal production, Ukraine remains a supplier of coal to a number of countries. In 2016, Ukraine exported 520.6 tons of coal worth $\$ 44.76$ million. Ukrainian coal was exported mainly to Slovakia for $\$ 26.88$ million, to the Russian Federation for $\$ 7.48$ million and to Turkey for $\$ 7.1$ million. Exports to other countries in 2016 amounted to $\$ 3.29$ million [29].

In our opinion, this area of cooperation looks the most illogical one, because due to the loss of Donetsk and Luhansk coal basins in 2014, Ukraine increased its imports, respectively, coal exports to Turkey should have stopped, but it did not happen. Therefore, after the beginning of the Russian aggression against Ukraine, the coal trade and development of its deposits are still nonurgent and not so important spheres of Ukrainian-Turkish cooperation due to the Russian aggression in the East of Ukraine.

\subsection{Renewable power generation}

In 2017, renewable energy comes to the forefront in bilateral energy cooperation. The future ways of cooperation between Ukraine and Turkey were discussed by the Head of the State Agency for Energy Efficiency S. Savchuk and the Extraordinary and Plenipotentiary Ambassador of the Republic of Turkey to Ukraine Mr. Yönet Can Tezel during the meeting at the Agency in December of 2017.

According to the Ambassador, Turkey is actively implementing "clean" energy projects and is among the top 10 countries in the world in terms of wind and hydropower capacity introduced in 2016, and is actively working to install solar power plants. Some Turkish companies are interested in working in Ukraine and are already planning to build wind power plants in Zakarpattia, Lviv and Ivano-Frankivsk regions. It was agreed that the joint efforts of Ukraine and Turkey in this area would be mutually beneficial for both countries, so the possibility of signing a Memorandum of Understanding in the fields of energy efficiency, renewable energy and alternative fuels between the State Agency for Energy Efficiency and the relevant Turkish agency was considered. Bilateral cooperation will stimulate the implementation of "green" projects in Ukraine with the participation of Turkish companies and investments [30].

In 2019, at the forum organized by the Chamber of Commerce and Industry of Ukraine "Ukraine-Turkey 2019: Business Partnership without Borders" K. Hura, a representative of the State Agency for Energy Efficiency, called on Turkish business and investors to strengthen cooperation with Ukraine in the field of electrical energy and heat from renewable sources; installation of plants for the production of equipment in "clean" energy; energy generation from garbage; improving energy efficiency in buildings, industry, etc. K. Hura said: "Ukraine and Turkey can strengthen efforts for mutually beneficial projects aimed at reducing energy dependence, reducing $\mathrm{CO}_{2}$ emissions and at the same time ensuring sustainable community development" [31].

Prospects for cooperation between Ukraine and Turkey in support of renewable energy can be described as lowprobability and unproductive, despite the calls of the representative of the company for efficient use of energy $\mathrm{K}$. Hura and the documents concluded between Ukraine and Turkey in this area. The following facts can serve as a proof of this. Thus, in Turkey, renewable energy generation facilities received incentive payments of about \$570 million in June. In total, 817 facilities with a capacity of 21,049 MW received financial support. In Turkey, the renewable energy support scheme was launched in 2011. It provides for payments to wind and hydropower plants, as well as geothermal power plants and plants that generate electricity from solar energy, for each kilowatt-hour $(\mathrm{kWh})$ generated at pre-determined tariffs. As a result of programs to support alternative and local energy sources, the share of renewable electricity in the country reached $62 \%$ in 2019 [32]. In Ukraine, the 
government is going in the opposite direction and the chairman of the Fuel and Energy Committee of the Verkhovna Rada A. Herus said that in 2020 energy production from renewable sources in Ukraine would grow rapidly and there would be a problem with the compensation for "green tariff", otherwise some nuclear power plants would be turned off, and energy produced at nuclear power plants was much cheaper [33]. So, the problem of reducing the "green tariff" in Ukraine arises for the second time (2019 and 2020). And a logical rhetorical question arises as to how profitable it will be for Turkish businessmen to invest in Ukrainian renewable energy under such conditions.

\subsection{The electrical power sector}

Regarding the electrical power sector, apart from regulatory documentation, we found no other evidence of cooperation between Ukraine and Turkey in this area. In general, we note that the production and export of electricity after 2014 in Ukraine fell significantly (the decline in electricity exports also occurred in 2009 and 2010).

\section{CONCLUSION}

Summing up the results of the research, we note that the topic in Ukrainian and Turkish scientific circles is not very studied, which is because Ukrainian-Turkish cooperation in the field of energy is a situational impulse rather than strategic balance, despite the fact that Turkey has been a strategic partner of Ukraine since 2011. The regulatory and legal framework for energy cooperation is presented in a number of documents, but not too in-depth in the field of electrical power or renewable energy generation. We believe that the regulatory and legal framework for energy cooperation should be strengthened by detailing it. The development of new bilateral documents slowed down after 2011.

The regulatory framework envisages the goals of Ukraine and Turkey to cooperate in the framework of international projects for the construction of the Nabucco Gas Pipeline and the Samsun-Ceyhan Oil Pipeline, which have not been implemented so far. As the result, Ukraine has not been able to coordinate its policy on joint transportation of oil and gas and a joint search for their deposits with Turkey, and we believe that it has lost this opportunity, because Turkey discovered its own rich gas fields on its own Black Sea shelf afterward. So, Turkey cares about its own interests in ensuring its own energy security and its possible transformation into a global energy hub, and Ukraine has failed to provide strong arguments to convince Turkey.

In the field of coal energy, Turkey lost its interest in Ukraine after 2014 and the loss of access to the main coal basins in the east of Ukraine. Further Ukrainian-Turkish cooperation in this area seems illogical, as Ukraine is no longer able to sell coal to Turkey in the same amount, so its exports to Turkey have decreased significantly. Given the fact that Ukraine has increased coal imports at times, the coal trade and development of its deposits are still non-urgent and not so important spheres of UkrainianTurkish cooperation due to the Russian aggression in the East of Ukraine.

Regarding the cooperation between Ukraine and Turkey in the field of a peaceful nuclear use, Ukraine has not used its potential in this area, as well as in hydrocarbons despite Ukraine's uranium reserves and significant experience in the operation of nuclear power plants in Ukraine.

Ukrainian-Turkish cooperation in renewable energy generation at this stage looks promising, one that can attract investment. However, as the issue of reducing the "green tariff" arises for the second time in Ukraine (2019 and 2020), deepening cooperation in this area does not seem realistic.

Therefore, given the significant Ukrainian energy reserves (although insufficient) and the important transit role of Ukraine, we see the prospects for energy cooperation between Ukraine and Turkey and the possibility for Ukraine to realize its interests in ensuring energy independence (in particular, possible solutions to political and technical problems concerning the passage of LNGtankers across the Bosporus and the Dardanelles Straits to supply raw materials to the Ukrainian LNG terminal). Joint activities on the implementation of projects for the modernization of the gas transmission system and other energy infrastructure facilities of both countries (especially given the fact that this is provided for in bilateral agreements) also look promising. There are prospects in the nuclear sector, as Ukrainian companies could provide subcontracting services for the Turkish coal industry, the creation and operation of nuclear power plants in Turkey.

However, it is worth emphasizing that time is running out and those projects and opportunities that seem important and real today may become simply unattainable tomorrow. In particular, the joint search for oil and gas fields on the Black Sea shelf is no longer as relevant for Turkey as it has been before the summer of 2020, when it has discovered significant gas deposits and has the necessary equipment for further searches. Turkey may lose interest in cooperating with Ukraine in the energy sector and come a level of competition for its transit position and importance, which undermines Ukraine's importance as a transit country, especially taking the construction of the Trans-Anatolian Oil Pipeline into consideration.

We should also add that Ukraine's opportunities for a mutually beneficial equal partnership with Turkey in the energy sector diminished after the Russian aggression in eastern Ukraine, as Ukraine temporarily lost some of its resources, which could become the object of bilateral interests. In addition, Ukraine demonstrated its inability to ensure security and stabilize the situation in the country. 


\section{ACKNOWLEDGMENT}

I would like to thank my supervisor - Doctor of Historical Sciences, Professor of the International Relations and Foreign Policy Department, Head of the Department Oleksander Petrovych Tryhub for valuable advice and significant recommendations in the implementation of my research.

\section{REFERENCES}

[1] "Zelensky and Erdogan discussed further cooperation between Ukraine and Turkey". InterfaxUkraine. News agency. 23.08.2020. [“'Зеленський i Ердоган обговорили подальшу співпрацю України i Туреччини”. Інтерфакс-Україна. Інформаційне агенство. 23.08.2020. URL:

https://ua.interfax.com.ua/news/investments/682919.ht $\mathrm{ml}$ [ [in Ukranian]

[2] Total energy consumption. World Energy Statistical Yearbook 2020. URL:

https://yearbook.enerdata.net/total-energy/worldconsumption-statistics.html [in English]; Total energy production.World Energy Statistical Yearbook 2020. URL: https://yearbook.enerdata.net/total-energy/worldenergy-production.html [in English].

[3] World energy economy. EES EAEC. [Мировое энергетическое хозяйство. EES EAEC URL: http://www.eeseaec.org/mirovoe-energeticeskoehozajstvo] [in Russian].

[4] Analytical report. "Trends in the security situation in the Black Sea region". Center for Global Studies “Strategy XXI". July 2020. Kyiv. [ Аналітичний звіт. Тенденції безпекової ситуації у Чорноморському регіоні. Центр глобалістики “Стратегія XXI”. Липень 2020. Київ. URL:

https://geostrategy.org.ua/analityka/analitychnazapyska/analitychnyy-zvit-tendenciyi-bezpekovoyisytuaciyi-u-chornomorskomu-regioni/zavantazhytyanalitychnyy-zvit-ukr ][in Ukranian]

[5] O.S. Mavrina, "Strategic Partnership in the Foreign Policy Practice of Turkey" Oriental Studies. 2012. № 59. S. 48-81. [О. С. Мавріна Стратегічне партнерство в зовнішньополітичній практиці Туреччини. Сходознавство] 2012. No. 59. С. 48-81. URL: https://oriental-studies.org.ua/wpcontent/uploads/2016/01/978-966-02-6993-4.pdf [in Ukranian]

[6] O. Koliada, "Strategy of trade and economic cooperation between Ukraine and Turkey". International economic policy. Kyiv: KNEU. 2012 pp.182-187. [О. Коляда. “Стратегія торговельноекономічної співпраці України та Туреччини”. Міжнародна економічна політика. Київ: КНЕУ. 2012. C. pp.182-187] [in Ukranian]

[7] P. Enverov, "Conceptualization of the bilateral strategy of Ukrainian-Turkish economic relations in the conditions of deepening European integration". Scientific Bulletin of the Lesia Ukrainka East European National University. International relations. 2013. No. 10. pp. 244-252 [Р. Енверов, “Концептуалізація двосторонньої стратегії українсько-турецьких економічних відносин в умовах поглиблення євроінтеграції. Науковий вісник

Східноєвропейського національного університету імені Лесі Українки. Міжнародні відносини. 2013. No.10. C. pp.244-252] [in Ukranian]

[8] O. Vladimir, L. Malyuta, "Historical preconditions and modern economic and political necessity of deepening Ukrainian-Turkish cooperation”. Bulletin of Donetsk University of Economics and Law. Issue No.2. 2015. pp. 156-202. О. [Владимир, Л. Малюта, “ІІторичні передумови та сучасна економікополітична необхідність поглиблення українотурецького співробітництва”. Вісник Донецького університету економіки та права. Випуск.No.2. 2015. C. pp.156-202]. [in Ukranian]

[9] C. Kakişım, "Karşılıklı Bağımlılık Kapsamında Türkiye-Rusya Enerji İlişkilerinin”. An Analysis of Turkey and Russia Energy Relations in the Scope of Interdependenceю International Journal of Political Science. Uluslararası Siyaset Bilimi ve Kentsel Araştırmalar Dergisi Cilt 7, Sayı 1, Mart 2019. S.pp.67-89. DOI: 10.14782/ipsus.539186 [in Turkish]

[10] Gareth M.Winrow, "Energy security in the Black Sea-Caspian region”. Perceptions. Autumn 2005. pp.85-98.

[11] İ. Kemaloğlu, “Türkiye-Ukrayna ilişkileri çok yönlü gelişiyor. 09.08.2019. URL:

https://www.aa.com.tr/tr/analiz/turkiye-ukraynailiskileri-cok-yonlu-gelisiyor/1553369 [in Turkish]

[12] Protocol on Cooperation in the Field of Energy between the Government of Ukraine and the Government of the Republic of Turkey. Date of signing: October 28, 1993. Entry into force: October 28,1993 . [Протокол про співробітництво в галузі енергетики між Урядом України і Урядом Турецької Республіки. Дата підписання: 28 жовтня 1993 р. Набуття чинності: 28 жовтня 1993 р. URL: 
https://zakon.rada.gov.ua/cgibin/laws/main.cgi?nreg=792_044\#Text] [in Ukranian]

[13] Agreement between the Government of Ukraine and the Government of the Republic of Turkey on the Ceyhan-Samsun oil pipeline system. Ratification dated 17.12.1997 [Угода між Урядом України і Урядом Турецької Республіки про нафтопровідну систему Джейхан-Самсун. Ратифікація від 17.12.1997].

URL:

https://zakon.rada.gov.ua/laws/show/792_001\#Text [in Ukranian]

[14] Law of 17.12.1997 No. 739/97-BP On Ratification of the Agreement between the Government of Ukraine and the Government of the Republic of Turkey on the Ceyhan-Samsun Oil Pipeline System Закон від 17.12.1997 № 739/97-ВР [Про ратифікацію Угоди між Урядом України і Урядом Турецької Республіки про нафтопровідну систему Джейхан Самсун.]. URL: https://zakon.rada.gov.ua/cgibin/laws/main.cgi?nreg=739/97-

$\%$ D0\%B2\%D1\%80\#Text [in Ukranian]

[15] Memorandum of Understanding between the State Nuclear Regulatory Committee of Ukraine and the State Atomic Energy Agency of the Republic of Turkey on technical cooperation and exchange of information in the field of nuclear regulation. Date of signing: 07.06.2005. Date of entry into force for Ukraine: 08.09.2005. URL:

https://zakon.rada.gov.ua/cgi-

bin/laws/main.cgi?nreg=792_066\#Text [Меморандум про взаєморозуміння між Державним комітетом ядерного регулювання України та Державним агентством Турецької Республіки 3 питань атомної енергетики щодо технічного співробітництва та обміну інформацією в сфері ядерного регулювання. Дата підписання: 07.06.2005. Дата набрання чинності для України: 08.09.2005. URL:

https://zakon.rada.gov.ua/cgibin/laws/main.cgi?nreg=792_066\#Text] [in Ukranian]

[16] Memorandum of Understanding between the State Nuclear Regulatory Committee of Ukraine and the State Atomic Energy Agency of the Republic of Turkey on technical cooperation and exchange of information in the field of nuclear regulation. URL: https://zakon.rada.gov.ua/cgibin/laws/main.cgi?nreg=792_066\#Text [Меморандум про взаєморозуміння між Державним комітетом ядерного регулювання України та Державним агентством Турецької Республіки з питань атомної енергетики щодо технічного співробітництва та обміну інформацією в сфері ядерного регулювання. URL: https://zakon.rada.gov.ua/cgibin/laws/main.cgi?nreg=792_066\#Text] [in Ukranian]

[17] Agreement between the Government of Ukraine and the Government of the Republic of Turkey on cooperation in the field of energy (The Agreement was approved by the Resolution of the Cabinet of Ministers No. 1058 (1058-2005-n) of November 5, 2005) Date of signing: June 7, 2005. Date of approval by Ukraine: November 5, 2005. Date of entry into force for Ukraine: 30.12.2011 [Угода між Урядом України та Урядом Турецької Республіки про співробітництво в галузі енергетики ( Угоду затверджено Постановою КМ N 1058 ( 1058-2005-п ) від 05.11.2005 ) Дата підписання: 07.06.2005. Дата затвердження Україною. 05.11.2005. Дата набрання чинності для України: 30.12.2011

URL:https://zakon.rada.gov.ua/laws/show/792_046\#Te xt] [in Ukranian]

[18] Karar Sayısı: 2008/13475. “Türkiye-Ukrayna Hükümetlerarası Ticari ve Ekonomik İşbirliği Komisyonu VI. Dönem Toplantısı Protokolü’ nün onaylanmas1. 28 Mart 2007 tarihinde Kiev'de imzalanan ekli Resmî Gazete. 20 Nisan 2008. Pazar. URL:https:/www.resmigazete.gov.tr/eskiler/2008/04/2 0080420-1.htm [in Turkish]

[19] Memorandum of Understanding in the field of energy between the Ministry of Energy and Coal Industry of Ukraine and the Ministry of Energy and Natural Resources of the Republic of Turkey date of signing: 25.01.2011, date of entry into force for Ukraine: 25.01.2011. [Меморандум про взаєморозуміння у галузі енергетики між Міністерством енергетики та вугільної промисловості України і Міністерством енергетики та природних ресурсів Турецької Республіки дата підписання: 25.01.2011, дата набрання чинності для України: 25.01.2011.] URL:

https://ips.ligazakon.net/document/MU11004 [ in Ukranian]

[20] Memorandum of Understanding in the field of energy between the Ministry of Energy and Coal Industry of Ukraine and the Ministry of Energy and Natural Resources of the Republic of Turkey. Date of signing: 25.01.2011. Date of entry into force for Ukraine: 25.01.2011 [Меморандум про взаєморозуміння у галузі енергетики між Міністерством енергетики та вугільної промисловості України і Міністерством енергетики та природних ресурсів Турецької Республіки. Дата 
підписання: 25.01.2011. Дата набрання чинності для України: 25.01.2011.] URL:

https://zakon.rada.gov.ua/laws/show/792_075\#Text [in Ukranian]

[21] Agreement between the Government of the Union of Soviet Socialist Republics and the Government of the Socialist Republic of Romania on the transit of Soviet natural gas through the territory of the Socialist Republic of Romania to Turkey, Greece and other countries. (Moscow, December 29, 1986). [Угода між Урядом Союзу Радянських Соціалістичних Республік і Урядом Соціалістичної Республіки Румунії про транзит через територію Соціалістичної Республіки Румунії радянського природного газу в Туреччину, Грецію та інші країни. (Москва, 29 грудня 1986 року)]. URL: https://zakon.rada.gov.ua/cgibin/laws/main.cgi?nreg=642_046\#Text [in Ukranian]

[22] O. Volovich, "Hybrid economic cooperation between TR and RF". Independent think tank for geopolitical research. Borisfen Intel. 16.04.2020. [О. Волович Гібридне економічне співробітництво між ТР і РФ. Незалежний аналітичний центр геополітичних досліджень. Борисфен Інтел. 16.04.2020. URL:

https://bintel.org.ua/analytics/voenni-voprosy/konfliktzones/gibridne-ekonomichne-spivrobitnictvo-mizh-tr-i$\mathrm{rf} /]$ [in Ukranian]

[23] Cooperation between Ukraine and Turkey in various fields. Ministry of Economic Development and Trade of Ukraine. State support of Ukrainian exports. [Співробітництво між Україною та Туреччиною у різних галузях. Міністерство економічного розвитку і торгівлі України. Державна підтримка українського експорту].URL:http://www.ukrexport.gov.ua/ukr/econ _spivirob/tur/6417.html [in Ukranian]

[24] M. Vorotnyuk, "Foreign Policy Audit: UkraineTurkey", invited expert of the Institute of World Politics. April 13, 2016, Glavkom "Ukrainian Media Systems”. [М. Воротнюк, “Аудит зовнішньої політики: Україна-Туреччина”, запрошений експерт Інституту світової політики. 13 Квітня, 2016, “Главком" “Українські медійні системи”]. URL: https://glavcom.ua/publications/334345-auditzovnishnoji-politiki-ukrajina-turechchina.html [in Ukranian]

[25] Ukraine and Turkey will cooperate in nuclear energy, May 13, 2016, Ukrainian Pravda. [Україна та
Туреччина співпрацюватимуть в атомній енергетиці, 13 травня 2016, Українська правда. URL:

https://www.epravda.com.ua/news/2016/05/13/592581/ ] [in Ukranian]

[26] Ukrayna'dan Türkiye'ye nükleer enerji için işbirliği teklifi.Anadolu Ajansı web sitesinde, AA Haber Akış Sistemi (HAS) 09.02.2016. URL: https://www.aa.com.tr/tr/dunya/ukraynadan-turkiyeyenukleer-enerji-icin-isbirligi-teklifi/518399 [in Turkish]

[27] An agreement on cooperation in the field of training nuclear specialists was signed in Ankara. 12/5/2019 [В Анкарі підписали угоду про співпрацю в сфері підготовки спеціалістів-ядерників.

5.12.2019.URL: https://www.ukrinform.ua/rubricsociety/2831917-v-ankari-pidpisali-ugodu-prospivpracu-v-sferi-pidgotovkispecialistivadernikiv.html] [in Ukranian]

[28] Türkiye ile Ukrayna arasında maden işbirliği. Kaynak: AA. Giriş 15.02.2012 Güncelleme. URL: https://ekonomi.haber7.com/ekonomi/haber/844969turkiye-ile-ukrayna-arasinda-maden-isbirligi [in Turkish]

[29] Review of the Ukrainian coal market. August 15, 2017. Analytical reviews. [Огляд українського ринку енергетичного вугілля. 15 серпня 2017. Аналітичні огляди. URL: https://kreston-gcg.com/ua/coal/] [in Ukranian]

[30] Ukraine and Turkey see prospects for mutually beneficial cooperation in renewable energy. State Agency for Energy Efficiency and Energy Saving of Ukraine. 30 Dec 2017 [Україна та Туреччина вбачають перспективи взаємовигідної співпраці у відновлюваній енергетиці. Державне Агенство 3 енергоефективності та енергозбереження України. 3012 2017. URL: http://saee.gov.ua/uk/news/2127] [in Ukranian]

[31] Turkey is a valuable partner for Ukraine in building "clean" energy and energy efficiency. Government portal. The only web portal of the executive authorities of Ukraine. December 21, 2019. [Туреччина - цінний партнер для України у розбудові “чистої” енергетики та енергоефективності. Урядовий портал. Сдиний вебпортал органів виконавчої влади України. 21 грудня 2019 року. URL: https://www.kmu.gov.ua/news/turechchina-cinnijpartner-dlya-ukrayini-u-rozbudovi-chistoyi-energetikita-energoefektivnosti] [in Ukranian] 
[32] Green energy. "GreenPost” July 21, 2020 [Зелена енергетика. "GreenPost” 21 Липня 2020. URL: https://greenpost.ua/news/turechchyna-vklala-uvidnovlyuvalnu-energetyku-shhe-piv-milyarda-dolarivi12121] [in Ukranian]
[33] E. Solonina "Green Tariff" can be given a "red light”. September 6, 2020, February 14, 2020 [ $€$.

Солонина "Зеленому тарифу” можуть дати “червоне світло”. 06 вересня 2020, 14 лютого 2020]. URL: https://www.radiosvoboda.org/a/30433020.html [in Ukranian] 